\title{
Ustanovitev sekcije za učenje in izobraževanje odraslih z zmerno, težjo in težko motnjo $v$ duševnem razvoju pri Andragoškem društvu Slovenije
}

$\mathrm{V}$

seživljenjsko učenje je $\mathrm{v}$ zadnjih letih pogosto omenjan, uporabljan, citiran in obravnavan pojem. Njegova kompleksnost je vse večja, vsebina vse širša in bogatejša. Širi se $\mathrm{v}$ različne sfere in na mnoga področja človekovega življenja. Tako bi vsaj moralo biti. Pa ni. Od Delorsovega ambiciozno zastavljenega koncepta učenja v 21. stoletju je ostalo malo, prevladal je ekonomistični model, ki ustrezno vrednoti in podpira le učenje za boljšo konkurenčnost in prožnost na trgu delovne sile. Vrednote, ki sestavljajo vrednostni sistem, temelječ na humanizmu, pa so podcenjene. Globalizacija družbe je poleg prednosti, ki bi jih lahko prinesla, zahtevala tudi svoj davek. Namesto da bi izkoristili prednosti lažjega povezovanja, lažje dostopnega potovanja, spoznavanja novih krajev in kultur, medsebojnega dialoga, prednosti novih tehnoloških komunikacijskih sredstev, se zdi, da svet drvi v neobvladljivo izkoriščanje in kopičenje materialnih dobrin peščice posameznikov, vsi preostali pa niso pomembni. Še zlasti ne tisti, ki spadajo na obrobje. Zaradi takšnih družbenih tokov je po našem mnenju podcenjeno, slabše vrednoteno učenje, ki je zajeto v preostalih treh »Unesco- vih stebrih«, pri čemer se pozablja, da prav te vrste učenje pomembno vpliva tudi na učenje za poklic in delo. Kajti človek je kompleksno bitje, ki ga ne moremo pojmovati kot skupka med seboj nepovezanih segmentov, ki drug na drugega ne vplivajo.

Tak družbeni kontekst ima močan vpliv tudi na učenje in izobraževanje ciljne skupine odraslih $\mathrm{z}$ zmerno, težjo in težko motnjo $\mathrm{v}$ duševnem razvoju. To se v praksi kaže med drugim kot neustrezno ali sploh odsotno oblikovanje učne in izobraževale politike ter posledično nerazvitost stroke, ki jo začenjamo poimenovati specialna in (re)habilitacijska andragogika.

Resda je bila življenjska doba ljudi z motnjo $\mathrm{v}$ preteklosti krajša, vendar pa bi bilo treba $\mathrm{v}$ prihodnje upoštevati, da demografskim gibanjem populacije brez motnje sledi tudi populacija ljudi z motnjo, to pomeni, da se tudi njim življenjska doba podaljšuje in nikakor ni res, da je njihovo število zanemarljivo.

Pri učenju in izobraževanju ljudi z zmerno, težjo in težko motnjo $\mathrm{v}$ duševnem razvoju se vedno znova srečujemo s predsodki in stereotipi, ki se jih uporablja, kadar se o nekem pojavu ali pojmu premalo ve oziroma je do- 
stopnih premalo informacij. Takrat se neka posameznikova lastnost generalizira, pri čemer ni prave osnove v dejanskem stanju, oziroma se ne preverja dejstev. Tako stereotip kot predsodek vplivata na položaj posameznika v družbi, vedno pa imata negativen oziroma slabšalen predznak.

$\mathrm{Z}$ uvidom $\mathrm{v}$ naše, slovensko, pojmovanje in vrednotenje učenja in izobraževanja smo soočeni z informacijo, da ima za vladajoče strukture neko vrednost le šolanje, pa še to le učenje in izobraževanje, ki je formalizirano in ki se izvaja pretežno $\mathrm{v}$ otroštvu in mladostništvu. Vrednost vse pestrosti in bogastva, ki ju ponuja učenje in izobraževanje v odrasli dobi in na starost, pa je v sistemu potisnjeno na obrobje, kar je povsem transparentno $\mathrm{v}$ grafični shemi našega šolskega sistema.

Upoštevajoč ta uvid (ki v podrejen položaj potiska že učenje in izobraževanje ljudi brez motnje oziroma, kot tudi pravimo, brez posebnih potreb) se seveda ne smemo čuditi stanju, ki vlada na področju učenja in izobraževanja odraslih z motnjo v duševnem razvoju (če seveda sploh smemo govoriti o področju), zlasti še z zmerno, težjo in težko motnjo. Tu se seveda takoj pojavlja vrsta vprašanj in dilem, od smiselnosti in racionalnosti ter potrebnosti pa vse do statusa odraslega. Vse prevečkrat se te ljudi zgolj zaradi intelektualnega primanjkljaja obravnava kot otroke, »večni otrok « je že skoraj splošno sprejeta sintagma, pa čeprav gre na primer za gospo ali gospoda v starosti štiridesetih, petdesetih let. V andragoškem kontekstu pa o statusni odraslosti te ciljne skupine ne bi smeli dvomiti, saj andragoška definicija odraslosti ne govori o značilnostih osebe same, temveč o položaju osebe $\mathrm{v}$ izobraževalnem procesu, ali kot pojasnjuje to definicijo dr. Sabina Jelenc Krašovec: po tej opredelitvi ni pomembno, ali je posameznik sposoben samostojnega mišljenja in odločanja, kako sprejema samega sebe, kako in na kakšni stopnji poteka njegova komunikacija $\mathrm{z}$ drugimi in podobno, temveč ga kot odraslega opredeljujemo na pod- lagi družbenih vlog, ki jih ima. Prav družbena vloga pa je tista, ki posamezniku podeljuje (ne) moč in vpliv na lastno življenje.

Ugotavljamo torej, da je relativno dobro urejeno začetno izobraževanje (če zanemarimo nenehno težnjo snovalcev politike po zniževanju starostne meje, ko so otroci in mladostniki z motnjo še upravičeni do javnega in obveznega šolanja), medtem ko je možnosti in priložnosti za učenje in izobraževanje v odrasli dobi za to ciljno skupino bore malo.

Prav tako pa so te možnosti in priložnosti, če že so, bolj ali manj segregirane, namenjene samo udeležencem $\mathrm{z}$ motnjo, kar pa je v nasprotju $\mathrm{z}$ evropskimi smernicami, ki propagirajo integracijo in inkluzijo. Tudi tukaj je premik v izvajanju začetnega izobraževanja bil narejen, medtem ko za odrasle udeležence integracija, še zlasti pa inkluzija le stežka prodirata v učno-izobraževalno ponudbo.

Zaradi tega se je pojavila potreba po dejavnosti skupine strokovnjakov, ki želi uveljaviti pravico do učenja in izobraževanja te ciljne skupine kot vseživljenjsko in vseobsegajočo. Priložnost je dobila v Andragoškem društvu Slovenije, kjer se je predvsem po zaslugi in močni podpori predsednika društva, dr. Zorana Jelenca oblikovala sekcija, v kateri so našli svoje mesto zainteresirani za razvoj učenja in izobraževanja odraslih z zmerno, težjo in težko motnjo v duševnem razvoju. Pri tem je treba poudariti, da so značilnosti in potrebe te skupine vendarle tako specifične, da jih ne moremo obravnavati skupaj z drugimi skupinami oseb s posebnimi potrebami.

Sekcija je imela svoj prvi sestanek 22. septembra 2008. Prisotnih je bilo le nekaj članov, ki pa so vendarle naredili prvi korak v dokaj optimističnem načrtu dela.

Pripravljen je tudi že program delovanja, ki je kompleksen in obsežen, za izvedbo pa bo potrebnih več let, saj nas realne družbeno-ekonomske razmere navdajajo s skrbjo, z nastankom gospodarskih kriz pa so vedno najprej na udaru dejavnosti, ki nimajo takojšnjega ma- 
terialnega učinka ali se jih pojmuje zgolj kot porabnike proračunskega denarja.

Program predvideva uresničevanje naslednjih nalog:

1. pregled stanja na tem področju v Sloveniji;

2. nadaljevanje pridobivanja članov sekcije in somišljenikov;

3. sledenje in seznanjanje s tujimi raziskavami o izobraževanju odraslih z motnjo $\mathrm{v}$ duševnem razvoju ter prenos $\mathrm{v}$ domačo prakso;

4. promocija izobraževanja in učenja odraslih z motnjo v duševnem razvoju različnim naslovnikom (starši, politični subjekti, izvajalske organizacije IO, različne javnosti...) ter iskanje inovativnih oblik in pristopov promocije;

5. dejavnosti, s katerimi bi poskušali presegati stereotipe in predsodke o učnih in izobraževalnih potrebah ciljne skupine in smiselnosti učenja in izobraževanja (razstave, javno objavljanje dosežkov, različna informativna gradiva...);

6. dejavno poseganje v oblikovanje politike vseživljenjskosti učenja za to ciljno skupino v Sloveniji;

7. promocija Strategije vseživljenjskosti učenja;

8. usklajevanje, razvijanje, raziskovanje, apliciranje terminologije;

9. omogočanje izmenjave dobrih praks (slovenskih in tujih) na različne načine;

10. spodbujanje izmenjave znanja in izkušenj med slovenskimi izvajalci IO ciljne skupine;

11. spodbujanje učno-izobraževalne ponudbe, namenjene odraslim z motnjo $\mathrm{v}$ zasebnih in javnih izvajalskih organizacijah za IO ter razvojno-raziskovalnih ustanovah (ljudska univerza, zasebne organizacije, društva, Univerza za tretje življenjsko obdobje, ACS, centri za vseživljenjsko učenje, Borza znanja, svetovalna središča...);

12. nadaljevanje uveljavljanja pravice do učenja in izobraževanja ciljne skupine na osnovi ratificiranih domačih in evropskih dokumentov;
13. spodbujanje povezovanja specialne in rehabilitacijske pedagogike in andragogike;

14. dajanje pobud za ustrezni študijski program na pedagoški in filozofski fakulteti;

15. spremljanje aktualnih dogodkov ter odzivanje nanje;

16. sodelovanje $\mathrm{z}$ ustreznimi asociacijami s področja specialne in rehabilitacijske pedagogike;

17. sodelovanje s preostalimi komisijami in sekcijami ADS ter strokovnjaki;

18. vključevanje študentov andragogike ter specialne in rehabilitacijske pedagogike $\mathrm{v}$ dejavnost sekcije;

19. organiziranje strokovnih posvetov, konferenc in drugih dogodkov;

20. skrb za prenašanje informacij in novitet andragogike na področje specialne in rehabilitacijske pedagogike;

21. vključevanje v andragoške projekte po načelu normalizacije;

22. publiciranje $\mathrm{v}$ domačih in tujih strokovnih revijah;

23. iskanje možnosti in priložnosti za razvojno in raziskovalno delo ter umestitev $\mathrm{v}$ sistem.

$\mathrm{Na}$ koncu naj zapišemo še vabilo za vse tiste, ki vas delovanje sekcije zanima in ki ste pripravljeni sodelovati, pa doslej k sodelovanju še niste bili povabljeni. Dobrodošel je vsak, ki ima voljo in je pripravljen prispevati $\mathrm{k}$ uresničevanju zastavljenih ciljev programa, ki ima na voljo različne vire, ki bi pripomogli k uspešnosti, in je pripravljen pripomoči k sinergetskemu učinku delovanja.

Kontaktna oseba: mag. Alenka Golob, alenka. golob@guest.arnes.si

GSM 041775 813, 01/366 3222 